\title{
Mackie Was Not an Error Theorist
}

\author{
Selim Berker \\ Harvard University \\ sberker@fas.harvard.edu \\ [Penultimate draft of a paper published in \\ Philosophical Perspectives 33 (2019): 5-25.]
}

\section{Introduction}

John Mackie was not an error theorist. This is a bald statement of the thesis of this essay, but before arguing for it I shall try to clarify and restrict it in ways that may meet some objections and prevent some misunderstanding.

The statement of this thesis is liable to provoke one of two different reactions. Some will think it not merely false but absurd; how can Mackie, who gave us the term 'error theory' and used it to describe his own view in metaethics, fail to be an error theorist? Others will regard my thesis as true but uninteresting, perhaps because the exact details of how Mackie formulated his view diverge from the exact details of how we think the error theory is best formulated nowadays. But, precisely because there can be these two different reactions, more needs to be said.

The claim that Mackie was not an error theorist, despite his having bequeathed that term to us, is not absurd because many terms in philosophy now mean something different from what they initially meant when they were first introduced into the philosopher's lexicon. 'Deontology' was originally a neologism created by Jeremy Bentham to refer to a utilitarian's theory of how the deontic depends on the evaluative, but these days it denotes the primary competitor to utilitarian moral views. 'Consequentialism' is now the more general term for the class of moral views into which utilitarianism falls, but the term was coined by Elizabeth Anscombe to refer to only a specific form of what we now call 'consequentialism', namely those varieties of act-consequentialism that deny a "distinction between foreseen and intended consequences, as far as responsibility is concerned” $(1958,12)$. 'Supervenient property' was originally introduced - I suspect but cannot definitively prove - as a synonym for 'resultant property' or 'consequential property', both of which meant 'property that obtains in virtue of other properties', but now has come to mean 'property that 
necessarily covaries with certain other properties'. ${ }^{1}$ Thus, just as, on Gareth Evans' $(1973,196)$ telling, 'Madagascar' at first referred to a portion of the African mainland but now refers to a large island off Africa's coast, so too do these terms - 'deontology', 'consequentialism', 'supervenient property' - in our mouths denote something different from what they were originally utilized by philosophers to denote. I shall be arguing that the same thing has occurred with the label 'error theory' in metaethics: it no longer means what Mackie introduced it to mean.

'Error theory about morality' these days refers to the thesis also known as 'moral nihilism', according to which there is no such thing as moral goodness or badness, moral rightness or wrongness, moral requirement or permission, moral virtue or vice, or any other moral category or quality, just as there are no such things as witches or phlogiston. It is controversial how best to formulate the error theory, so construed. Does it follow on this view that moral sentences are false, or that they are neither true nor false? (I shall sidestep this issue by saying they are untrue.) Does it follow on this view that all moral sentences are untrue, or that it is only the positive, atomic moral sentences that are untrue? (A standard puzzle for the latter proposal: given that being permitted and being required are duals of one another, how do we settle which is the positive, atomic property?) These controversies suggest a cheap, uninteresting way of arguing that Mackie was not an error theorist: first argue that 'error theory' as we use the phrase today refers to one of these ways of understanding nihilism (maybe: the view that all positive, atomic moral sentences are neither true nor false), and then argue that Mackie defended a different way of understanding nihilism (maybe: the view that all moral sentences are false). This is not my strategy. I shall be arguing that Mackie was not any kind of moral nihilist.

Mackie opens Chapter 1 of Ethics: Inventing Right and Wrong by telling us the chapter's main thesis: "There are no objective values." Mackie quickly clarifies that he is using 'value' as a normative catch-all that covers not just evaluative categories such as goodness and badness, but also deontic categories such as duty and obligation and aretaic categories such as being contemptible and being rotten. On the standard

\footnotetext{
1 See Berker 2018, 733-35. For this use of 'resultant property' and 'consequential property', see Ross 1930, 28, 33, 79, 88, 121-22. For use of 'supervenient property' as a synonym of 'consequential property', see Hare 1954, 80, 131. For evidence that 'supervenient property' was widely used in Oxford during the years between the publication of these two books, see Hare $1984,1$.
} 
interpretation of him, Mackie not only thinks that objective values (requirements, virtues, etc.) do not exist, but also thinks that moral values (requirements, virtues, etc.) would have to be objective to exist at all. So on the standard interpretation, Mackie is a moral nihilist. For instance, here is how Mackie's most famous argument from this chapter - the argument from queerness - runs on the standard interpretation, when it is directed against the existence of moral obligations in particular:

P1. It is built into the meaning of moral terms (and concepts) that the expression 'moral obligation' (and concept MORAL OBLIGATION) refers to something objectively prescriptive. [semantic/conceptual premise]

G1. So, if moral obligations exist, they are objectively prescriptive. [initial conclusion]

P2. Nothing in the world is objectively prescriptive. [substantive premise]

C2. So, moral obligations do not exist. [final conclusion]

There is then an internal debate among advocates of the standard interpretation over whether to say that moral obligations are objectively prescriptive is to say that they are intrinsically motivating (i.e. to subscribe to the thesis known as "internalism about motives"), or to say that they are inherently reason-giving (i.e. to subscribe to the thesis known as "internalism about reasons").2

After teaching this material for many years, I have come to the conclusion that the standard interpretation is wrong. Mackie does not think that moral values would have to be objective to exist at all. He never explicitly says this, and there are good reasons to think he does not hold such a view. On my interpretation, Mackie's real conclusion is not that moral values do not exist, but rather that moral values exist but only as subjective values. So on my interpretation, Mackie is not a moral nihilist. As I read him, Mackie is an advocate of morality's mind dependence who holds that moral values, requirements, virtues, and so on depend on our subjective concerns (on our desires, goals, choices, decisions, and so on). Morality, for Mackie as I interpret him, is not found but created. Hence his book's subtitle: Inventing Right and Wrong. ${ }^{3}$

2 For instance, David Brink $(1984,1986)$ interprets Mackie as appealing sometimes to internalism about motives and other times to internalism about reasons, whereas Richard Garner (1990) and Richard Joyce (2001) interpret Mackie as appealing only to internalism about reasons.

3 Lecture notes in which I present my non-standard interpretation of Mackie and lay out much of the support for it found below have been available online since 2006. More recently, Victor Moberger (2017) has published his own non-standard interpretation of Mackie. Moberger cites my lecture notes and explicitly builds on some of the same evidence I marshal in favor of my interpretation. Although he and I agree on one key issue — that Mackie is no moral nihilist — there are several other interpretative 


\section{Five Pieces of Evidence}

Since my interpretation goes against assumptions built into nearly every published discussion of Mackie, since it conflicts with the way Mackie's chapter has almost always been taught in metaethics courses over the past four decades, it needs very solid support. But such support can be found. I start by presenting five central pieces of evidence in favor of my interpretation; but, as we shall see, there are more pieces of evidence beyond these to be uncovered.

- First piece of evidence: Mackie is extremely careful only to deny the truth of the claim to objectivity that is built into ordinary moral thought and talk, rather than denying the truth of every single moral claim we make, in a way that is difficult to make sense of on the standard interpretation.

Here are the two key passages in which Mackie explains what he means by 'error theory':4

But the denial of objective values will have to be put forward not as the result of an analytic approach, but as an 'error theory,' a theory that although most people in making moral judgments implicitly claim, among other things, to be pointing to something objectively prescriptive, these claims are all false. (35)

Moral skepticism must, therefore, take the form of an error theory, admitting that a belief in objective values is built into ordinary moral thought and language, but holding that this ingrained belief is false. (48-49)

These passages are frequently misread. When Mackie writes "these claims are all false" at the end of the first passage, 'these claims' does not refer back to 'moral judgments'; rather, it refers to the 'implicit claim[s]

... to be pointing to something objectively prescriptive' that such judgments make. And when Mackie writes "this ingrained belief is false" at the end of the second passage, 'this ingrained belief' does not refer back to 'ordinary moral thought'; rather, it refers to the 'belief in objective values' that is built into such thought. So in neither passage is Mackie asserting that all first-order moral judgments or sentences are false. Instead, it is the "implicit claim" or "ingrained belief" that comes with those judgments and sentences that is being declared to be false.

This pattern holds elsewhere. Compare:

The assertion that there are objective values or intrinsically prescriptive entities or features of some kind, which ordinary moral judgments presuppose, is, I hold, not meaningless but false. (40)

points where we part ways. See n. 17 below.

4 Unless otherwise specified, all parenthetical page references are to Mackie 1977a. 
Considerations of these kinds suggest that it is in the end less paradoxical to reject than to retain the commonsense belief in the objectivity of moral values, provided that we can explain how this belief, if it is false, has become established and is so resistant to criticisms. (42)

But aesthetic values are less strongly objectified than moral ones; their subjective status, and an 'error theory' with regard to such claims to objectivity as are incorporated in aesthetic judgments, will be more readily accepted .... (43)

In all five of the passages quoted so far, ${ }^{5}$ Mackie distinguishes two things:

i. $\quad$ our ordinary first-order moral (and aesthetic) thought and talk; and

ii. an "implicit claim"/"ingrained belief"/"assertion" that is "built into"/"incorporated in"/ "presuppose[d]" by that thought and talk, according to which moral (and aesthetic) values are objective.

Moreover, Mackie meticulously words his sentences so that it is only the second of these that is being said to be false, according to his error theory. On the standard interpretation of Mackie, it is completely mysterious why he does this. If he thinks that both first-order moral claims and the claim to objectivity built into them are untrue, why put so much effort into carefully constructing his sentences so that it is only the latter that is being asserted to be untrue?

This recurring pattern is a powerful piece of evidence for my interpretation. Mackie does not define his error theory as the view that first-order moral sentences are false, or neither true nor false. Instead, he defines it as the view that a certain assumption built into ordinary first-order moral sentences is false, namely one on which moral values are objectively prescriptive. His error theory (what he meant by the term 'error theory') is an error theory only about the claim to objectivity built into ordinary moral thought and talk; our error theory (what we mean by the term 'error theory' nowadays) is an error theory about all of moral thought and talk.

- Second piece of evidence: Mackie never once says that there are no moral values.

Mackie repeatedly tells us that the main thesis of his chapter is that there are no objective values. (Forty six times, by my count.) And he occasionally characterizes his main thesis as the claim that there are no objective moral

\footnotetext{
5 And in numerous other passages elsewhere: see, for instance, ibid., 225; Mackie 1977b, 138; and Mackie 1980, 141-42.
} 
values. (Fourteen times, by my count.) But he never once says that his main thesis is that there are no moral values. He never once denies the existence of moral values or requirements - although he does explicitly deny the existence of "objective values or requirements" (17). He never once wonders how there could be moral values and how we could know them - although he does frequently wonder "how values could be objective" (24) and how we could come to know them if they were. He never once speaks of an act's "supposed moral qualities" - although he does talk of "the supposed objectivity of moral qualities" (42). Moreover, some of Mackie's ways of phrasing his central conclusion only make sense if there are moral values. At one point he writes that "moral values are not objective" (18), and at another he mentions "the moral values whose objectivity I am denying" (30); note that both expressions entail the existence of moral values. The most plausible explanation of why all of this is so: Mackie is only objecting to the supposition that moral values are objective, not to the supposition that they exist. That is why the chapter is titled "The Subjectivity of Values," not "The Non-Existence of Moral Values." To hold that Mackie denies the existence of objective values, of objective moral values, and of moral values but just happened to never formulate his central thesis in this third way is to attribute an astounding coincidence to the manner in which he ended up expressing his views in writing.

Now we need to be careful when pressing this point, for the term 'value' is ambiguous (or, more precisely, is polysemous: it has multiple interconnected meanings). When 'value' is used as a count noun, sometimes it refers to a valuable (something that is to be valued: a normative category), sometimes it refers to a valued (something that is in fact valued by someone: a descriptive category), and sometimes it refers to $a$ valuing (someone's act or attitude of valuing something: another descriptive category). For instance, the sentence "American values include hard work and apple pie" uses 'value' in this second way, and "She has firm values" uses it in the third. Could it be that Mackie avoids the phrase "There are no moral values" because (i) it is most natural to hear that sentence as using 'value' in either our second or our third way; (ii) when we hear the sentence in these ways, it also most natural to take 'moral' to modify the type of valuing at issue, rather than the type of thing being valued; and (iii) Mackie does not mean to deny that people value things in a distinctively moral manner - does not mean to deny that there is an attitude of moral valuing 
that people bear toward certain actions and entities? The idea here is that, by contrast, "There are no objective moral values" and "There are no objective values" force us to interpret 'value' as 'thing to be valued', which is why Mackie prefers these formulations.

However, this alternate hypothesis cannot be used to undermine the evidence I am citing here. To begin with, there is no parallel distinction for 'goodness', 'obligation', 'fittingness', or 'ought', so this proposal does not explain why Mackie never once says that there is no moral goodness, no moral obligation, no moral fittingness, or no moral 'ought', although he is perfectly comfortable denying the existence of objective goodness $(25,143)$, of objective moral obligations $(199,239)$, of objective fittingness (40, 82), and of an objective moral 'ought' (224). But more importantly, it is simply false that "There are no moral values" is most naturally read as using 'values' to mean either 'valueds' or 'valuings'. I have trouble hearing 'values' as meaning anything other than 'valuables' in that sentence, and others report having a similar reaction. By way of comparison, if a philosopher were to write, "There are no epistemic values," I don't think any of us would interpret her as denying that there are objects of a distinctively epistemic type of valuing, as opposed to denying that there is a distinctively epistemic type of thing-to-be-valued. Similarly, the sentence "There are no second-order values" cannot be refuted by pointing to the existence of valuings of valuings. In short, we cannot explain away Mackie's puzzling refusal to assert that there are no moral values by appealing to ambiguities in 'value'-talk.

- Third piece of evidence: My interpretation makes better sense of why Mackie calls himself a subjectivist.

Another key piece of evidence comes from Mackie's choice of nomenclature. In addition to 'error theory', one of Mackie's names for the metaethical position he defends in Chapter 1 of Ethics: Inventing Right and Wrong is 'moral subjectivism' (17-18). ${ }^{6}$ But 'moral subjectivism' is highly misleading -indeed, utterly baffling - as a name for moral nihilism. However, it is not misleading at all as a name for the view that moral values are subjective.

\footnotetext{
6 Actually, it is not clear to me that Mackie even intends 'error theory' to be a name for his proposal, as opposed to a description of the type of theory that it is: an (not the) error theory, since it attributes an error to ordinary moral thought and talk (on my reading, the error of taking moral values to be objective, not the error of taking first-order moral claims to be true).
} 
- Fourth piece of evidence: My interpretation makes better sense of why Mackie takes his view to be compatible with semantic subjectivism.

After telling us that 'subjectivism' is a name for the second-order view he will be defending, Mackie distinguishes his view from two other views that are also sometimes called 'subjectivism':

i. a first-order view according to which "everyone really ought to do whatever he thinks he should"; and

ii. a different second-order view from the one he defends, namely "the doctrine that, for example, 'This action is right' means 'I approve of this action', or more generally that moral judgments are equivalent to reports of the speaker's own feelings or attitudes" (17).

He goes on to insist that this different second-order view - call it 'semantic subjectivism' - is compatible with his own second-order view:

It is true that those who have accepted [semantic subjectivism] have usually presupposed [my view]. It is because they have assumed that there are no objective values that they have looked elsewhere for an analysis of what moral statements might mean, and have settled upon subjective reports. (18)

But how could semantic subjectivism be compatible with Mackie's error theory, if the latter is a form of moral nihilism? If "This action is morally right" means "I approve of this action," then whenever I approve of an action (a possibility Mackie does not deny: he is no eliminativist about the mental), it will be true that the action in question is morally right.

In fact, matters quickly get worse for the standard interpretation. Mackie immediately adds that not only is semantic subjectivism compatible with his view, but moreover semantic subjectivism "entails" his view (at least when his view is restricted to those types of moral value that we are "aware of" and hence have terms for in our language), although "the converse entailment does not hold" (18). On the standard interpretation, Mackie is making a gross logical error here: semantic subjectivism about moral discourse most certainly does not entail moral nihilism (even when restricted to those moral values for which we have terms). But on my interpretation, he is making no mistake at all: semantic subjectivism about moral discourse does plausibly entail that moral values are not objective (or, at least, does plausibly entail that the moral values for which we have terms are not objective). 
- Fifth piece of evidence: My interpretation makes better sense of why Mackie takes his view to be compatible with the possibility of doing first-order normative ethics.

In Part II (Chapters 5-8) of Ethics: Inventing Right and Wrong, Mackie goes on to argue for a particular theory in normative ethics, a kind of mixed consequentialist-deontological theory. But Mackie would have to be seriously confused to think that, although there's no such thing as morality, we can still theorize about which theory of right and wrong is the correct one. This is a commonly cited interpretative puzzle, usually brought up in order to make jokes at Mackie's expense. Gilbert Harman's $(1985,80)$ quip is typical: “It is almost as if [Mackie] had first demonstrated that God does not exist and had then gone on to consider whether He is wise and loving." However, there is no puzzle here on my interpretation: second-order metaphysical moral subjectivism of the sort I am ascribing to Mackie is perfectly compatible with first-order moral theorizing. It strains credulity to think that a philosopher as talented as Mackie did not recognize the tension between endorsing second-order moral nihilism and engaging in first-order moral theory.

The possibility of a clash between his metaethical and normative-ethical views is not an issue that Mackie merely overlooked, or simply forgot to consider. He explicitly tells us, on the second page of Chapter 1, that his second-order views about the status of morality are compatible with "thoroughly conventional" first-order views about the content of morality (16). Moreover, his discussion of normative-ethical issues in Chapters 5-8 is shot through with references back to his conclusions from Chapter 1 . Several of these references make my interpretation particularly difficult to resist. He begins Chapter 5 by arguing that even though "there are no objective values" (not: "there are no moral values"), there is still work left to be done in moral philosophy, because " $[\mathrm{m}]$ orality is not to be discovered but to be made: we have to decide what moral views to adopt, what moral stands to take" (105-6; see also 123). Later, in Chapter 6, he points out that we can make better sense of Mill's infamous "proof" of the principle of utility if we attribute to Mill the assumption that some things are objectively good or intrinsically desirable, but he then rejects this way of arguing for first-order utilitarianism on the grounds that it is incompatible with the second-order position he took himself to have established earlier in the book:

[Mill's proof] is not blatantly fallacious. But it is not cogent for us, because the key assumption that something 
or other is intrinsically desirable, objectively good, has been undermined by the rejection of all objective values in Chapter 1. (143)

And, perhaps most tellingly, Mackie insists during his discussion of consequentialism and deontology in

Chapter 7 that we must reframe this debate in light of his conclusions from Chapter 1 :

The issue between deontology and consequentialism is often raised by asking "Should we always act so as to bring about the best possible results on the whole, or are there some things that must be done, and/or other that must not be done, whatever the consequences?" But if the main line of my arguments is accepted, the question in that form will be seen as misleading. There are no objective moral prescriptions of either sort. Our question must rather be, "Are all the guides to conduct that we want people to adopt, and all the constraints on conduct that we want them to accept, of the form 'Act so as to bring about $x$ as far as possible,' or are some of them of the form 'Do' (or 'Do not do ...') 'things of kind $y$ '?' (154-55)

In other words, what we must decide is not which among various competing consequentialist and deontological moral principles are objectively true, but rather which among those principles would best meet our subjective concerns were they adopted. These are not the words of a moral nihilist who has temporarily forgotten his nihilism while engaging in first-order moral theory, but rather the words of a metaethical subjectivist whose subjectivism consciously informs and inflects the way he approaches foundational questions in normative ethics. ${ }^{7}$ Mackie was a subjectivist, not an error theorist in our modern way of understanding that term.

\section{Five Pieces of Counter-Evidence?}

I have been focusing on the positive evidence for my subjectivist interpretation of Mackie. But in order to make my case, I should also consider the strongest pieces of potential counter-evidence. I focus here on five. Each takes the form of a leading question one might ask in order to challenge my interpretation.

- First piece of putative counter-evidence: "Doesn't Mackie in other places explicitly say that, on his view, all first-order moral sentences are untrue?"

Here are the two passage people usually have in mind when they ask this:

One way of stating the thesis that there are no objective values is to say that value statements cannot be either true or false. (25)

Does [my view] not at one stroke rule out all normative ethics, laying it down that all affirmative first order judgments are false, since they include, by virtue of the very meanings of their terms, unwarranted claims to

\footnotetext{
7 Other places where Mackie's subjectivist second-order commitments are explicitly brought to bear during his first-order arguments include 150-51, 159-60, 165, 173, 199, and 208-9.
} 
objectivity? (49)

But if one keeps reading, it becomes clear that in both places Mackie is not endorsing the possibilities he raises.

The passage from page 25 continues: "But this formulation, too, lends itself to misinterpretation. For there are certain kinds of value statements which undoubtedly can be true or false, even if, in the sense I intend, there are no objective values." He goes on to concede that on his view there can be objective evaluations "in relation to agreed or assumed standards," such as we find in "the grading of apples" and "the awarding of prizes at sheepdog trials" (25-26). Does this mean that, those kinds of cases to one side, he thinks value statements cannot be true or false? What he writes on these pages is compatible with that interpretation. But it is also compatible with my interpretation, since there might be more than one reason why a formulation of a thesis lends itself to misinterpretation. However, is it really the case that, on my interpretation, the formulation being discussed lends itself to misinterpretation when restricted to cases other than those involving evaluation relative to assumed standards, or is it that the formulation is just incorrect when restricted in that way? I must confess that my interpretation loses some plausibility points here- but not prohibitively so, in my opinion.

The passage from page 49 continues: "I shall take up these issues in Chapter 5." There are two "issues" being referred to here, which this passage takes to be equivalent: first, the issue of whether Mackie's metaethical view from Chapter 1 "at one stroke rule[s] out all normative ethics" and, secondly, the issue of whether that view "lay[s] it down that all affirmative first order [moral] judgments are false." Rather frustratingly, Mackie never explicitly returns to this second issue in Chapter 5. He does, however, address the first issue head-on. He opens Chapter 5 by insisting that it is still possible to engage in first-order ethics once we reject all objective values, provided we recognize that morality is (as already quoted) "not to be discovered but to be made" (106). He goes on in that chapter to argue for a particular "object" or point to morality, which forms the basis of nearly all of his subsequent arguments in normative and practical ethics in the remainder of the book. Thus Mackie's answer in Chapter 5 to his question in Chapter 1 of whether his metaethical view "at one stroke rule[s] out all normative ethics" is clearly a resounding "no." Moreover, 
given the assumed equivalence, in the page 49 passage, of that question to the question of whether his view entails that all affirmative first-order moral judgments are false, it is reasonable to infer that Mackie's answer to that second question is "no" as well. So, if anything, the page 49 passage (together with Mackie's subsequent discussion in Chapter 5) provides us with further evidence for my interpretation, rather than counter-evidence against it.

- Second piece of putative counter-evidence: "Why didn't Mackie correct people when they interpreted him as being a moral nihilist, after his book was published?”

Well, who is to say he didn't try to correct people? And even if he did try, he didn't have very long to do so, for Mackie died in 1981, a mere four years after the publication of Ethics: Inventing Right and Wrong.

Moreover, even though we do not have any published corrections of misguided interpretations of Chapter 1 of his 1977 book, we do have the next best thing: concurrent and later writings in which Mackie summarizes the view he took himself to be defending in that chapter. What is more, these summaries fit my interpretation to a striking degree. I mention here three examples. ${ }^{8}$

First, in an article published in 1977 on Ronald Dworkin's theory of law, Mackie writes,

So what law is, on Professor Dworkin's view, may crucially depend on what is morally best . . . Now I would argue, though I cannot do so here, that moral judgments of this kind [i.e. moral judgments about what is morally best] have an irreducibly subjective element. [footnote:] I have argued for this view in Chapter 1 of my Ethics: Inventing Right and Wrong....9

What is stressed here is the "irreducibly subjective element" of certain first-order moral judgments - an odd thing to stress, if Mackie were indeed an error theorist in our modern sense of that term.

Secondly, in his 1980 book Hume's Moral Theory, Mackie sees the British moral tradition from Hobbes to Reid as centrally concerned with "the debate over whether there are, or are not, objective moral values" (Mackie 1980, vii), with objectivists such as Clarke, Wollaston, Price, and Reid on one side and sentimentalists such as Hutcheson, Butler, Hume, and Smith on the other. Mackie argues that the most plausible form of objectivism is a form of intuitionism (1980, 74, 145), which he rejects on the basis of

8 Beyond these, see also Mackie 1978, 108; Mackie 1979b, 171; Mackie 1982b, 152-53; and Mackie 1984, 198.

9 Mackie 1977b, 9. I thank Nicolas Alfonsi for originally bringing this passage to my attention. 
arguments much like his argument from queerness (1980, 60-61, 146, 150), whereas the most plausible form of sentimentalism is what he calls 'the objectification theory' (1980, 74, 137, 145), according to which "[m] oral statements typically say that" an "objective quality, detected by [a] special moral sense" is "found in a certain action (etc.)," but "the features ascribed to actions (etc.) in the distinctively moral (categorical imperative) part of these statements are fictitious" (1980, 73-74). Moreover, Mackie tells us repeatedlyboth in this book (1980, viii, 158n1, 159n4) and elsewhere (1979a, 221n2; 1982a, 238; 1982b, 153n3)- that the objectification theory is the same view he defends in Chapter 1 of Ethics: Inventing Right and Wrong. So in these places he is taking that metaethical view to be a version of sentimentalism that is opposed to moral objectivism, not a version of moral nihilism that is opposed to both sentimentalism and objectivism.

Thirdly, in his 1982 book The Miracle of Theism, finished just prior to his death, Mackie once again characterizes his proposal from Ethics: Inventing Right and Wrong as a "Humean, sentimentalist, subjectivist, or naturalistic" view on which "morality is essentially a human, social, product" and "is basically a matter of feelings and attitudes" (Mackie 1982a, 254, 255; see also 115-18, 238-39). Far from seeing his earlier view as a form of moral nihilism, he in fact proclaims it to be "an adequate reply to nihilism about value" (1982a, 246).10 This is about as close as we can get to an explicit disavowal of the standard, nihilist interpretation of Mackie's metaethical views.

- Third piece of putative counter-evidence: "Doesn't my interpretation have trouble explaining why Mackie calls himself a moral skeptic?"

Earlier I touted my interpretation's ability to explain why he calls his position 'moral subjectivism' as a significant piece of evidence in its favor. But, advocates of the standard interpretation might retort, their interpretation can appeal to an equally compelling piece of evidence on the other side: namely, the fact that Mackie's third name for his metaethical view, beyond 'error theory' and 'moral subjectivism', is 'moral skepticism'. And although 'moral skepticism' is a standard synonym for 'moral nihilism', it is rarely if ever used as a synonym for 'moral subjectivism'.

\footnotetext{
10 Later on that same page he again calls his view "a reply to nihilism about goodness or value," and on the next page he makes it clear that by 'nihilism about value' he means 'nihilism about moral value'.
} 
I grant that it is a somewhat puzzling, on my interpretation, why Mackie calls his position 'moral skepticism'. But at one point Mackie explicitly tells us that his view's error theory about the claim to objectivity built into ordinary moral thought and talk is "what makes the name 'moral skepticism' appropriate" (35). So even if this isn't good grounds for using that label, Mackie apparently thought it was. Moreover, no interpretation can entirely explain all the data here, it seems to me. It is difficult to think of a single view for which the labels 'moral skepticism' (when not understood as a name for an epistemological thesis) and 'moral subjectivism' are both perfectly apt. And, it seems to me, advocates of the standard interpretation have a more difficult time explaining why Mackie calls his view 'moral subjectivism' than I have explaining why he calls his view 'moral skepticism'. So we do not have, on balance, grounds of support for the standard interpretation here; at most we have a piece of evidence against my interpretation that is offset by a slightly strong piece of evidence for my interpretation. ${ }^{11}$

Finally, it is worth noting that in all of his writings after Ethics: Inventing Right and Wrong, Mackie stopped referring to the view defended in that book as a form of "moral skepticism," instead preferring to call it a "subjectivist" (1979b, 171; 1980, 74; 1982a, 117, 254; 1982c, 214, 219), "sentimentalist" (1980, passim; 1982a, 116, 254, 255; 1982c, 219), "naturalistic" (1982a, 117, 254, 255), or "Humean" (1982a, 254; 1982c, 215) account of morality. This trend is evidence that Mackie came to appreciate that 'moral subjectivism' is a more accurate label for his metaethical view than 'moral skepticism' is.

- Fourth piece of putative counter-evidence: "Aren't there other ways of explaining what Mackie is up to in the normative-ethics chapters of his book, by for instance interpreting him to be a moral

11 My own view is that the label 'moral skepticism' is an unfortunate holdover from Mackie's earlier article "A Refutation of Morals" (1946). This piece - the first Mackie ever published - anticipates some of the themes and arguments from Chapter 1 of Ethics: Inventing Right and Wrong, although there are also some important differences. (In the article he claims that the argument from relativity for his view is more convincing than the argument from queerness [1946, 78], whereas in the book this assessment is reversed [1977a, 38]. In the article he appears to endorse a hybrid form of expressivism on which in saying, "This action is right," we usually both express our approval of the action and ascribe to it an objective moral quality that it does not have [1946, 80-82], whereas in the book I see no evidence that he endorses any form of expressivism.) The earlier article is also much less carefully written than Mackie's later book. His official target in that article is the view "that [judgments that actions or activities or states of affairs are right or good] are either true or false, and that the qualities with which they deal exist objectively" (1946, 78). In some places Mackie - rather misleadingly - calls acceptance of such a view "believing in morals" (1946, 78) and "belief in morals" (83), but elsewhere he - more accurately - refers to it as "[b]elief in the objectivity of moral qualities" (1946, 79) and "belief in moral objectivity" (83). I suspect that it was precisely this sloppiness, together, perhaps, with a youthful desire to shock, that led Mackie to call himself a 'moral skeptic' in this article, when really 'moral-objectivity skeptic' would have been a more apt designation. Similarly, the article really should be titled "A Refutation of the Objectivity of Morals," not "A Refutation of Morals." 
fictionalist?"

Richard Joyce endorses the standard interpretation, on which Mackie argues for moral nihilism in Chapter 1 of Ethics: Inventing Right and Wrong. But Joyce also thinks that we can make sense of what Mackie is doing in Part II of that book by interpreting Mackie to be a moral fictionalist. Moreover, Joyce (2005, 287-88) insists that Mackie's talk of morality being a "useful fiction" on the book's final page provides evidence for his fictionalist interpretation.

However, Joyce has misread Mackie. Here is what Mackie in fact says on the book's final page:

In so far as the objectification of moral values and obligations is not only a natural but also a useful fiction, it might be thought dangerous, and in any case unnecessary, to expose it as a fiction. This is disputable. (239)

I agree with Joyce that Mackie is exploring the idea that something is a useful fiction. However, I disagree with Joyce over what that something is. This passage might support Joyce's fictionalist interpretation had Mackie written, "In so far as moral values and obligations are not only a natural but also a useful fiction ...." But that is not what Mackie writes. Instead he writes, "In so far as the objectification of moral values and obligations is not only a natural but a useful fiction ...." (emphasis mine). It is only taking moral values to be objective that Mackie is suggesting might be thought a useful fiction, not taking there to be moral values. ${ }^{12}$ Rather than offering support for Joyce's fictionalist interpretation of Mackie, this passage constitutes yet another piece of evidence for my subjectivist interpretation.

Moreover, there is a second problem with Joyce's proposal that Mackie is a moral fictionalist. If Mackie were a fictionalist about moral discourse, we would expect his discussion of issues in normative ethics in Chapters 5-8 of his book to make repeated appeals to the pragmatic benefits and costs of engaging with one or another "moral story" as a fiction in order to determine which of these stories (a consequentialist tale? a deontological yarn?) should serve as the content of our fictitious morality. But when we turn to those chapters, we find nothing of the sort. It is true, as already noted, that Mackie does not adjudicate issues in first-order moral theory in a traditional manner: rather than appealing to our intuitions about whether a

12 Furthermore, Mackie is not here endorsing the claim that morality's objectivity is a useful fiction; rather he brings up this possibility only to dispute that such a fiction would be useful and hence best left unexposed. Compare the final page of Hume's Moral Theory, where Mackie writes, "[M]orality is less likely to have these regrettable side-effects if it is understood. . . We are more likely to get its benefits without its disadvantages if we see through its claim to . . objective authority" (1980, 156, second emphasis mine). 
candidate moral principle is correct or whether the verdicts it yields in particular cases are plausible, he prefers to assess whether the widespread adoption of that principle would promote our subjective concerns, goals, and interests. However, what is at issue here is whether to "adopt" (106, 147, 148, 152, 154, 159, 168, 173, 176), "accept" (106, 120, 138, 148, 150, 152, 153, 154, 155, 165), or be "guid[ed]" by (106, 126, $131,151,154,155,157)$ a given principle, in the perfectly standard use of those terms, with no implicit qualifications or hidden subscripts, not whether to "fictively adopt" them, "accept them as a fiction," or "pretend to be guided by" them. There is no evidence that Mackie had anything like a fictionalist approach to moral discourse in mind when he wrote the normative-ethical chapters of Ethics: Inventing Right and Wrong. ${ }^{13}$ Mackie is no fictionalist. ${ }^{14}$

- Fifth piece of putative counter-evidence: "Isn't it extremely uncharitable to attribute such an implausible theory of presupposition to Mackie?"

It might seem that, on my interpretation, Mackie holds that a judgment or sentence can presuppose something untrue without itself being rendered untrue. And it might seem that this theory of presupposition is too implausible to charitably attribute to Mackie.

However, we should not be led astray by the word 'presuppose' here. There is only one place where Mackie uses that word to characterize the relationship between the claim to objectivity and ordinary moral thought and discourse (40); more often he talks of the claim to objectivity being an "assumption" of (35),

13 Mackie does occasionally mention fictions and myths during these chapters, but not in a way that undermines my reading. At one point, Mackie says that the main lesson of a line of thought due to Hobbes, Hume, and others is "the practical value of the notion of obligation, of an invisible and indeed fictitious tie or bond" (119). But here he is referencing his earlier discussion of the etymological origins of the word 'must', on which it was metaphorically linked, via the expression 'is bound to', with "a physical tying down" (76); what Mackie is claiming to be invisible and a fiction is that physical tying down, not the obligation to which it is metaphorically linked (that is why 'fictitious' modifies 'tie or bond', not 'obligation', in the sentence quoted). And at another point, Mackie proclaims that "[t]he utilitarian calculus is a myth, and not, I think, a helpful one" (139; see also the reference to utilitarianism's "characteristic fictions" on 200). But here he is decrying an aspect of utilitarianism that we, as theorists, can see to be mythical, not assessing whether we, as subjects, should engage with utilitarianism in a special, "pretend to be true" way. (Also, the 'and not . . . a helpful one'-clause is very much an afterthought in this paragraph, not the primary grounds on which utilitarianism is being rejected, as it would need to be on a fictionalist reading of this stretch of argument.)

14 Even if Mackie is not a fictionalist moral nihilist, could he instead be a conservationist moral nihilist, who advocates our continuing to hold moral beliefs and assert moral sentences because of their pragmatic benefits, despite their being untrue? This interpretation avoids the problem just mentioned, that Mackie does not consider anything like a notion of fictive belief or fictive assertion during his discussion of which first-order moral view we should adopt. But the conservationist interpretation faces a new problem: usually conservationists consider whether the practical advantages of moral beliefs and assertions outweigh the practical costs that accrue to them due to their being untrue, but we find no such discussion in Mackie's chapters on the content of morality. Moreover, a conservationist interpretation cannot be motivated by anything Mackie says on the book's final page. 
being "incorporated in" (35, 42, 43), being "ingrained in" (35, 49), or being "built into" $(35,49)$ such thought and discourse. And even in the one place where Mackie does use the word 'presuppose', surely he does not mean this in the modern sense of the term familiar from contemporary linguistics and philosophy of language, for judgments outside of a conversational context, not just sentences or speech acts within a conversation, can presuppose things in Mackie's sense. To avoid such confusion, I will use the term 'implicit assumption' instead of 'presupposition' from this point on.

Moreover, even if the theory of implicit assumption I am attributing to Mackie does at first seem implausible, it might still be the case that the best way of interpreting Mackie involves attributing just such a theory to him. Mackie endorses some peculiar views about the relationship between what is built into the conventional meaning of our terms (or concepts) and what is true of the things to which those terms (or concepts) refer. In the early pages of Chapter 1 of Ethics: Inventing Right and Wrong, Mackie makes a prescient distinction between what he calls 'factual analysis' and 'linguistic or conceptual analysis' (19). ${ }^{15}$ He then clarifies that his main thesis that there are no objective values should be taken to be an instance of factual analysis, not of linguistic/conceptual analysis. ${ }^{16}$ Among those who make such a distinction these days, it is common to hold that factual analyses do not entail linguistic/conceptual analyses. Justified true belief might be the real definition of knowledge without 'justified true belief' being the linguistic definition of 'knowledge'.) But Mackie also holds the quite radical view that the converse entailment fails as well, so that linguistic/conceptual analyses do not entail factual analyses. (Thus 'justified true belief' might be the linguistic definition of 'knowledge' without justified true belief being the real definition of knowledge!) That is why he says "linguistic and conceptual analysis is not enough" when it comes to determining whether moral values are objective (35).

The way in which Mackie allows that factual analyses might pull apart from linguistic analyses in

15 Here he builds on his earlier defense of this distinction in Mackie 1973, ch. 1.

16 Mackie assumes that conceptual analysis is the same thing as linguistic analysis, and more generally that conceptual questions (about the composition of our concepts) and linguistic/semantic questions (about the meanings of our words) always have corresponding answers. He regularly employs the 'or' of identity when mentioning "linguistic or conceptual" issues (18, 19); at one point he slides from talk of "linguistic inquiry" to talk of "conceptual analysis" within the same sentence, as if these are the same thing (19); and, more generally, whether he formulates a claim in terms of word meaning or concept composition appears to be a matter of indifference to him (many times he simply states both formulations, using an appositive clause to suggest their equivalence). 
both directions is by making a subtle distinction between

i. $\quad$ the meaning simpliciter of a word; and

ii. the meaning of a word in its standard, conventional sense.

What Mackie labels 'linguistic analyses' are really only analyses of (ii), not (i). This qualification allows him to say that a given linguistic analysis of some term might not carry over to the factual analysis of the entity picked out by that term. He provides a helpful analogy to illustrate how this might be so:

Naive realism about colors might be a correct analysis not only of our pre-scientific color concepts but also of the conventional meanings of color words, and even of the meanings with which scientifically sophisticated people use them when they are off their guard, and yet it might not be a correct account of the status [i.e. the metaphysical nature] of colors. (20)

So really Mackie's theory of implicit assumption amounts to the following claim: a sentence can implicitly assume something untrue given the standard, conventional meaning of its terms without the sentence itself being rendered untrue.

Recognizing this last distinction of Mackie's - between the meaning simpliciter of a word and the standard, conventional meaning of a word - allows us not only to see Mackie's theory of implicit assumption in a more positive light, but also to appreciate a further piece of evidence for my subjectivist interpretation. Whenever Mackie mentions the claim to objectivity that his error theory denies, he always, without fail, adds a qualifier to the sort of moral thought and talk that presupposes this claim to objectivity: he does not say that all moral thought and talk builds in the claim to objectivity, but rather that "common" (96, 102), “conventional" (20, 23, 35, 63, 102, 120), "ordinary" (31, 33, 35, 37, 40, 42, 48, 49, 60, 63, 72, 73, 79, 82, 225), "standard" (20, 73), or "traditional" $(35,63,102)$ moral thought and talk does. On my interpretation, we can make sense of why such a qualifier is always there. But on the standard interpretation, which holds the claim to objectivity to be, for Mackie, a non-negotiable part of all moral thought and discourse, it is altogether unclear why Mackie would include that ever-present qualifier.

There is one last possibility to consider. On my interpretation, Mackie holds that ordinary moral thought and talk incorporates a false assumption without such thought and talk itself being rendered false (or neither true nor false). Would it be better to interpret Mackie as holding that such ordinary moral thought and talk, with its erroneous built-in assumption of objectivity, is always false, but non-ordinary 
moral thought and talk that is devoid of such an assumption can be true? ${ }^{17}$ I do not think so. This proposal cannot explain the initial piece of evidence I presented for my interpretation: if Mackie thinks that both ordinary moral discourse and the claim to objectivity built into it are false, why did he take such pains to construct his sentences so that it is only the latter that is being claimed to be untrue? The proposal also forces us to say implausible things about Mackie's color analogy. Do we really want to say that all ordinary first-order talk of colors is false, if it turns out such talk implicitly assumes a form of naive realism about colors that is not the true account of the nature of the colors themselves? It is far better to say that these built-in assumptions are false, but ordinary assertions such as "That shovel is red" or "This pen is blue" are nonetheless true.

\section{Conclusion}

I have maintained that the standard and nearly universal way of reading of Mackie is mistaken. My interpretation, then, has taken the form of an exegetical error theory: although it is customary to interpret Mackie as a moral nihilist who holds all first-order moral thought and talk to be false (or, at least, neither true nor false), this customary reading is wrong. Mackie is a metaethical subjectivist, a mind-dependence theorist about morality, not an error theorist as we use that term nowadays. The main considerations that favor my subjectivist interpretation are: first, the care Mackie takes in only asserting the falsity of the claim to objectivity built into ordinary moral talk and thought, not the falsity of all moral talk and thought;

17 This is close to Moberger (2017)'s proposal. According to him, Mackie still counts as an error theorist, albeit an error theorist only about most moral judgment and discourse, not about all moral judgment and discourse. Moberger (2017, 9n21) claims, in support of his interpretation, that "Mackie says that most moral judgments are false (35)," but I think this is a misreading of that page, for the reasons already mentioned. Moberger also suggests that Mackie is a "semantic pluralist" who holds there are two "strands" to moral discourse, one that is objectivist in character and involves an essential commitment to objective values, the other of which is non-objectivist and involves no such commitment. I worry that, on this interpretation, Mackie should hold that talk of 'moral values and requirements' is straightforwardly ambiguous; but why, then, didn't Mackie say there are no moral 1 values and requirements (where 'moral ${ }_{1}$ ' picks out the objectivist strand of moral discourse), although there are moral 2 values and requirements (where 'moral 2 ' picks out the non-objectivist strand)? So Moberger has trouble with my second piece of evidence. He also has trouble with my third piece of evidence, since there is no one way of reading 'moral' on which Moberger's Mackie counts as both a moral subjectivist and a moral error theorist. (Mackie, on his interpretation, is at best a moral 2 subjectivist and a moral 1 error theorist.) Finally, Moberger interprets Mackie as endorsing a hybrid form of expressivism with regard to the non-objective strand of moral discourse, on which moral statements of that sort "both describe natural facts and express the speaker's conative attitudes" $(2017,7)$. I think there is some evidence that this was Mackie's view in "A Refutation of Morals" (1946, 80-82), but I see no evidence that he continued to hold such a view in Ethics: Inventing Right and Wrong, where Mackie is uniformly critical of expressivist proposals.

(I do not agree with Moberger that when Mackie says, in passing, that someone who speaks within an institution "joins in expressing its demands" (75), we should take this as an invocation of expressivism in our modern sense, and anyway this one stray line strikes me as too sleight a piece of evidence for attributing any expressivist commitments to Mackie.) Still, Moberger and I agree about the essential issue: Mackie was not a straightforward moral nihilist, and the standard way of interpreting him is incorrect. 
secondly, the conspicuous absence of a denial of the existence of moral values, despite the presence of many denials of the existence of objective values and of objective moral values; thirdly, the fact that Mackie calls his view 'subjectivism'; fourthly, the difficulty the standard interpretation has explaining why Mackie takes his metaethical position to be compatible with semantic subjectivism; fifthly, the corresponding difficulty the standard interpretation has explaining why Mackie bothered to explore issues in first-order ethics in the remainder of his book. These five points sum up the initial case for my interpretation; but in the course of our investigation of potential counter-evidence against my reading, we unearthed four additional avenues of support for my interpretation: first, the manner in which his ensuing discussion in Chapter 5 suggests that Mackie does not believe his view "at one stroke" to "rule out all normative ethics" and "la[y] it down that all first order [moral] judgments are false" (49); secondly, the striking ways in which Mackie asserts a subjectivist reading and denies a nihilist reading of Chapter 1 of Ethics: Inventing Right and Wrong in his other writings; thirdly, the mention he makes of treating the objectivity of moral values as a useful fiction on that book's final page; and, fourthly, the difficulty the standard interpretation has explaining why Mackie always includes an 'ordinary' or 'conventional' qualifier when discussing the sort of moral thought and talk that incorporates a claim to objectivity. It must be conceded, though, that although a majority of the pieces of potential counter-evidence we considered were found wanting, two of them could not be entirely dismissed. Why, on my reading, does Mackie merely say that formulating his thesis as the claim that value statements cannot be true or false "lends itself to misinterpretation," rather than saying that it is outright inaccurate (25)? And why, on my reading, does Mackie also label his position 'moral skepticism' in addition to 'subjectivism' (16)? Although these considerations count slightly against my interpretation, they are heavily outweighed by the nine pieces of evidence we have amassed on the other side of the ledger. All things considered, we should read Mackie as a moral subjectivist in the sentimentalist tradition, not as a trailblazer for contemporary moral error theory.

But what if we can establish this negative conclusion, that Mackie was not an error theorist? Does it help us to say anything positively within metaethics? One version of this essay would now go on to argue that Mackie's actual position is a neglected option that deserves to be taken seriously in contemporary 
metaethical debates. I, however, cannot in good faith be the author of such an essay, for it is not clear to me that my Non-Standard Mackie, the subjectivist, is a more interesting figure than Standard Mackie, the nihilist. I say this in part because Mackie leaves the details of his preferred form of subjectivism so vague. It is all well and good to say that " $[\mathrm{m}]$ orality is not to be discovered but to be made: we have to decided what moral views to adopt, what moral stands to take" (106), and that "[m]oral entities — values or standards or whatever they may be - belong within human thinking and practice: they are either explicitly or implicitly posited, adopted, or laid down" (Mackie 1978, 108). But which acts or attitudes have this magic power to make moral standards come into existence, and how exactly do they have it? Must the moral views we adopt with regard to one basic normative category — such as goodness, or wrongness, or rights, or reasonsdetermine the standards that apply to us with regard to all other categories, or are we free to decide even on the explanatory relations among normative categories? And how do we handle the almost-inevitable case in which several standards or values or goals that conflict with one another are at the same time adopted? Mackie says almost nothing about these delicate issues, so it is difficult to know even what his subjectivism amounts to, on my reading. ${ }^{19}$

Thus, rather than urging metaethicists to investigate the merits and faults of the position that Mackie in fact defends in his widely read, widely taught, and - if I am correct-widely misunderstood chapter on the subjectivity of values, instead I want to draw a different lesson from the exegetical arguments I have been offering here. Suppose I am right that almost all of us have been incorrectly interpreting Mackie for over four decades. This raises a disturbing possibility: how many other canonical texts have we been radically misreading in a similar way? At least some, no doubt. Therefore we should be careful when engaging with contemporary texts that have established readings, even very common ones, for perhaps those readings are founded on precisely the sorts of interpretative errors I have been trying to correct in the case of Mackie's attack on objectivist theories of moral value. ${ }^{20}$

19 In Mackie's defense, his reticence here is shared by most mind-dependence theorists and "Humean constructivists," who tend to avoid going into specifics about how, exactly, the facts about our decisions, goals, and "evaluative attitudes" determine the normative facts that apply to us. For further discussion of the complexities that arise here, see Berker 2014, 241-44.

20 I owe thanks for feedback on this material to Tyler Doggett (who once called my interpretation of Mackie 'heresy'), to an audience at the Chapel Hill Normativity Workshop, and to my students over the years in my metaethics course at Harvard. 


\section{References:}

Anscombe, G. E. M. 1958. "Modern Moral Philosophy." Philosophy 33: 1-19.

Berker, Selim. 2014. "Does Evolutionary Psychology Show That Normativity Is Mind-Dependent?" In Moral Psychology and Human Agency: Philosophical Essays on the Science of Ethics, edited by Justin D'Arms and Daniel Jacobson, 215-52. Oxford: Oxford University Press.

—. 2018. "The Unity of Grounding." Mind 127: 729-77.

Brink, David O. 1984. "Moral Realism and the Sceptical Arguments from Disagreement and Queerness." Australasian Fournal of Philosophy 62: 111-25.

—. 1986. "Externalist Moral Realism." Southern Fournal of Philosophy Supplementary Volume 24: 23-41.

Evans, Gareth. 1973. "The Causal Theory of Names." Aristotelian Society Supplementary Volume 47: 187-208.

Garner, Richard T. 1990. "On the Genuine Queerness of Moral Properties and Facts.” Australasian Foumal of Philosophy 68: 137-46.

Hare, R. M. 1952. The Language of Morals. Oxford: Oxford University Press.

—. 1984. "Supervenience." Aristotelian Society Supplementary Volume 58: 1-16.

Harman, Gilbert. 1985. "Is There a Single True Morality?” In Morality, Reason, and Truth, edited by David Copp and David Zimmerman, 27-48. Totowa, NJ: Rowan \& Littlefield. Reprinted in Harman 2000, 77-99. Page references are to the reprint.

—. 2000. Explaining Value and Other Essays in Moral Philosophy. Oxford: Oxford University Press.

Joyce, Richard. 2005. "Moral Fictionalism." In Fictionalism in Metaphysics, edited by Mark Eli Kalderon, 287-313. Oxford: Oxford University Press.

Mackie, J. L. 1946. "A Refutation of Morals.” Australasian Fournal of Philosophy 24: 77-90.

. 1973. Truth, Probability, and Paradox. Oxford: Oxford University Press.

-1977a. Ethics: Inventing Right and Wrong. London: Penguin Books.

—. 1977b. "The Third Theory of Law." Philosophy and Public Affairs 7: 3-16. Reprinted in Mackie 1985. Page references are to the reprint.

- 1978. "Can There Be a Right-Based Moral Theory?" Midwest Studies in Philosophy 3: 350-59. Reprinted in Mackie 1985, 105-19. Page references are to the reprint.

- 1979a. "Rights, Utility, and External Costs." Written in 1979 but first published in Mackie 1985, 220-33.

- 1979b. "The Three Stages of Universalization." Written in 1979 but first published in Mackie 1985, 170-83.

. 1980. Hume's Moral Theory. London: Routledge. 
—. 1982a. The Miracle of Theism. Oxford: Oxford University Press.

—. 1982b. "Cooperation, Competition, and Moral Philosophy." In Cooperation and Competition in Humans and Animals, edited by Andrew M. Colman. Wokingham, UK: Van Nostrand Reinhold. Reprinted in Mackie 1985, 152-69. Page references are to the reprint.

- 1982c. "Morality and Retributive Emotions." In Edward Westermarck: Essays on His Life and Works, edited by Timothy Stroup (Acta Philosophica Fennica). Reprinted in Mackie 1985, 206-219. Page references are to the reprint.

—. 1984. "Rights, Utility, and Universalization." In Utility and Rights, edited by R. G. Frey, 86-105. Minneapolis: University of Minnesota Press. Reprinted in Mackie 1985, 184-205. Page references are to the reprint.

- 1985. Persons and Values: Selected Papers, Vol. 2. Edited by Joan Mackie and Penelope Mackie. Oxford: Oxford University Press.

Moberger, Victor. 2017. "Not Just Errors: A New Interpretation of Mackie's Error Theory." Fournal for the History of Analytical Philosophy 5, no. 3: 1-12.

Ross, W. D. 1930. The Right and the Good. Oxford: Oxford University Press. 